\title{
The Change of Identity of the Javanese Deli through a Marriage Ceremony
}

\author{
Leylia Khairani \\ Universitas Muhammadiyah Sumatera Utara, Indonesia \\ leyliakhairani@umsu.ac.id
}

\begin{abstract}
The change in identity of the Javanese Deli was the result of a long historical journey consisting of several phases. The process of change was influenced by social interactions and processes that took place from the social conditions of the hometown, the migration to the plantations in Deli, to the outside of the plantation. The purpose of this research is how cultural identities are formed, constructed based on certain processes related to the history, context, and creativity of certain cultural actors to maintain their culture. The result of this research is that the culture of the Javanese Deli undergoes a process that is continuously being formed and changed. From this, it shows that the identity of the Deli Javanese is very much influenced by the changing situation and conditions compared to when they were in Java.
\end{abstract}

Keywords

identity, Javanese Deli; marriage

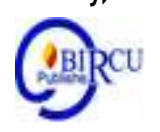

\section{Introduction}

Ethnicity as one that sustains a sense of primordialism is often interpreted as a social group in a social or cultural system that has a certain meaning or position because of heredity, customs, religion, language, and so on. Members of an ethnic group have a common history (ancestry), language, value system, customs, and traditions. Overall, the ethnic group takes an important position in the social interaction of the intermingling process in all ethnic groups of indigenous peoples in the social community. However, sensitivity to cultural differences is needed because an approach that is too fast can cause internal conflict for ethnicity itself. In such circumstances, the knowledge and skills of local leaders are needed to improve behavior in sensitive areas is very important (Angkat et al, 2019).

National cultural development means maintaining, preserving, protecting, spreading, utilizing and improving the quality of culture in a nation. This culture itself can be used as a source and reference in thinking of a nation to fit the norms and values that apply in the life of the nation and state. Culture is very complex, including knowledge, art, morals, law, customs, and other abilities obtained by humans as members of society. (Martozet and Nurwani, 2019). One characteristic of cultural studies is to focus on the subjective dimensions of social relationships, how certain social arrangements and configurations are lived and understood, thereby highlighting complex intersections between the public culture and personal subjectivity and possible transformative potentials (Srinarwati, 2018).

This paper aims to see that Javanese culture is not a homogeneous culture. From several anthropological research results, it is known that Java is not a homegene culture as previously imagined by many. There are several cultural variations, in which the Javanese see themselves differently from other Javanese. Javanese culture itself has sub-cultures, such as coastal Java, Java Osing, Java Suriname. With the differences in the sub-culture of the Javanese people which have distinctive cultural characteristics, it is an attraction for me to 
see Javanese people in North Sumatra. How do cultural aspects such as traditions and customs carried out by a Javanese community in North Sumatra become markers of their ethnic identity. In the following description I will see how cultural identity is formed, constructed based on certain processes related to the history, context, and creativity of certain cultural actors to maintain their culture.

\section{Review of Literature}

\section{Javanese Tradition of Marriage in Deli}

Koentjaraningrat argues that the distinctive characteristics of a culture can be manifested in limited elements, especially through language, arts, and ceremonies. Other elements find it difficult to highlight the distinctive characteristics of the culture of a nation or ethnic group. The identity marker of the culture of an ethnic group can be seen from the adat istidat which is mutually agreed upon and implemented. As stated by Maunati that:

"Identity markers can come from a uniqueness that is believed to exist in the religion, language and customs of the culture concerned".

Based on the concepts put forward by Koentjaraningrat and Maunati above, ceremonies in an ethnic group's culture are an important part of expressing an ethnic identity. The ceremonies performed by the Javanese are conceptualized as rites of the life cycle, which includes birth ceremonies, death ceremonies, and marriage ceremonies. Therefore, to see the distinctive characteristics of Javanese culture in Deli which can be used as a marker of their identity, it is possible to see it through the wedding ceremony that has been carried out until now.

In the case of the Javanese in Deli, the marriage that was carried out underwent a gradual change. This is related to historical factors and social life experienced in the plantation. The history of the arrival of the Javanese in Deli cannot be separated from the wave of migration to East Sumatra in the context of mobilizing labor in plantations since the late 19th century (Breman: 1997, Stoler: 1997, Pelzer: 1985, Said: 1977, Geertz: 1976, Lulofs: 1985).

In its development the Javanese who came to Deli were not limited to labor as laborers (coolies) on plantations, because along with the development of plantations and urban areas in East Sumatra there were also Javanese people who worked in the personnel sector, teachers, doctors, and others, especially since the early 20th century. Even though after independence there was still a steady flow of Javanese migration to East Sumatra, they were not many. If according to statistical data (BPS 2000) the population of Java in North Sumatra is 3 million people, then most of that number is descended from people who migrated during the colonial era of plantation in the late 19th to early 20th centuries.

Along with the growth and development of the plantation, there was high population mobility to the Deli area. In the early 20th century, due to the lively economic activity in East Sumatra, both the government and the private sector needed Javanese immigrants who had already attended school, for example to be employed as employees of the Opium Regie, crani-crani, and various assistants in the health sector including doctors. They came to Deli unlike the plantation Javanese who signed a work contract.

The interaction between Javanese Priayi and plantation Javanese who had left the plantation, and had lived in the urban periphery was possible because of the migration of Javanese laborers to outside the plantation area. As stoler which mentions that Javanese contract coolies who are old workers are generally from the first generation, who for the last fifty years have tried to distance themselves from the status of contract coolies, and most of 
them have concentrated their efforts on building their own houses and yards for small-scale agricultural production in the edges of the plantation or on land taken from the plantation.

The first generation that Stoler referred to above is the first generation that has succeeded in leaving the plantation. If calculated based on the genealogy of the early arrival of the Javanese to Deli around the end of the 1860s, after one generation who were the descendants or children of the plantation workers left the plantation around the 1890s. As also explained Stoler that the Javanese people every year have been displaced from the plantation environment, those who do not live in urban centers form a new sub-class in the interior by living in Malay villages on "borrowed" land as passengers and this kind of practice mentioned by Stoler to have been discovered by 1888. In these years they began to be outside the plantation community. They live on the fringes of the plantations and make a living from subsistence agriculture grown on land given by the plantation.

Next is Pelly revealed that since 1931 the Javanese ethnic group had spread outside the plantation areas into villages and cities in East Sumatra, including Medan. It was these groups that had left and withdrawn from the plantations that interacted with the priayis or Javanese elites in urban areas. This is possible because they distance themselves and leave the plantation after the contract period of work on the plantation ends. The awareness that emerged from within the Javanese who were former plantation workers made them more selective in choosing and adopting Javanese cultural symbols brought by priayis.

This is where the process of redefining who they are, the desire to distance themselves from the status of contract laborers shows that they indirectly have the awareness to redefine who they are. The emergence of awareness about identity occurs when they have separated from the plantation contract system and have lived in the villages of the villages which are their residence.

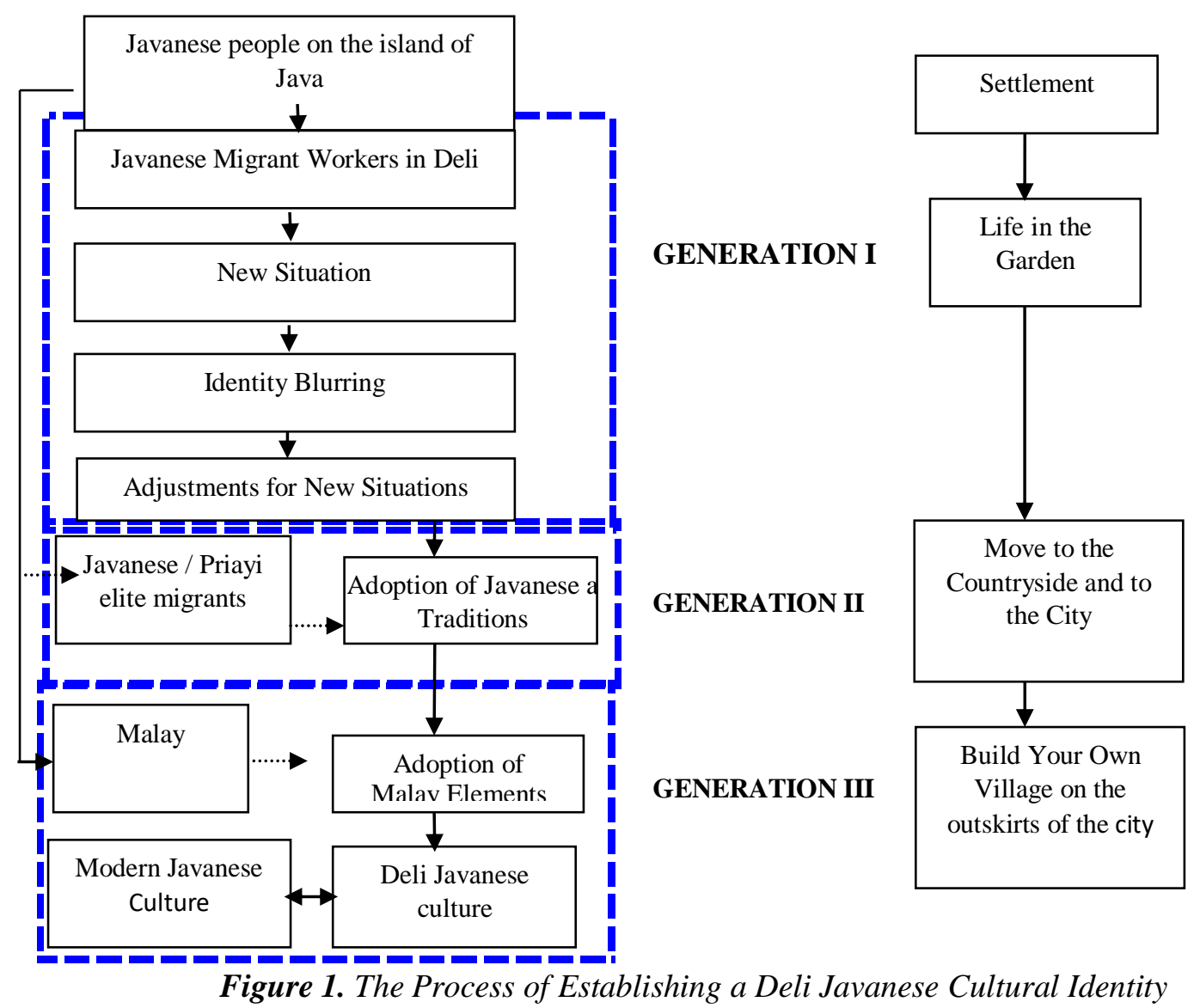




\section{Discussion}

\subsection{The Phase around the 1960 's}

In the implementation of the marriage in the 1970s around or on the outskirts of the plantation settlement area, it was seen that the elements used had not shown Javanese identity. A Javanese bride and groom who are having a wedding party and are held in a plantation community are seen wearing very simple clothes. The groom wears a suit complete with a tie which is paired with a long batik cloth or jarik. Meanwhile, the bride wears a simple kebaya that is paired with a finger.

In this regard, I see that the Javanese at that time tried or tried to adopt Javanese elements used by priayis, for example the blankon and batik cloth, twins and face ornaments. Certain elements adopted in the implementation of the wedding ceremony illustrate the existence of a process in adoption which will lead to the formation of their identity as Javanese which is expressed through the marriage ceremony. Confusion in the use of the adopted symbols and inaccurate use of Javanese symbols shows that they experience a disconnection from their identity and try to find their identity again.

Even though in this case, a cultural figure, especially the bridal midwife, has an important role in providing guidance and direction in the adoption. The bridal midwife is a guide for those who will use the type of traditional clothing to wear. Because every ethnic group wants to appear and carry out a wedding party according to the customs that become their identity. It seems that the elements of clothing and accessories used seem to force them to represent a Javanese culture.

In this regard, I see that the Javanese at that time tried or tried to adopt Javanese elements used by priayis, for example the blankon and batik cloth and face ornaments. Certain elements adopted in the implementation of the wedding ceremony illustrate the existence of a process in adoption which will lead to the formation of their identity as Javanese which is expressed through the marriage ceremony. Confusion in the use of the adopted symbols and inaccurate use of Javanese symbols shows that they experience a disconnection from their identity and try to find their identity again.

\subsection{The Phase around the 1980s until Now}

The bride and groom in this phase already wear the Solo Putri outfit which shows Javanese symbols that are increasingly clear with the use of the Jepara style aisle, besides that, the clothes used are the traditional Solo Putri clothing type. However, there are still irregularities, namely the blankon used by the groom. The blankon should not be used, but the long hat usually used by kings in the palace. Usually, in Java, the blankon is used in the type of ksatrian clothing, which is the clothing used by the bride and groom when the main event is over, or it can be said that the ksatrian clothes are used at a relaxed time before the completion of the wedding ceremony.

In the 2000s, the symbols used were the same as those used by Javanese brides on the island of Java. The groom no longer uses a blankon which is considered an irregularity in the use of Javanese Solo Putri traditional clothing. They began to wear long hats that match the clothes worn by the kings in the palace. Javanese clothes that are used are also more diverse. This happened because of the various facilities in accessing the growing trends in Java. The mobility of the population and knowledge about the models of traditional clothing from certain cultures are growing.

In the process of adopting Javanese symbols used by Deli Javanese brides, it shows that there is a process of searching for their Javanese identity. A process or series of symbolic actions adopting or using meaningful symbols of Javanese cultural markers in the Deli 
Javanese group is only limited to a model of clothing and aisle or a developing fashion trend. Other things which are principles in the ceremony cannot be changed and even integrated in the wedding ceremony that is held.

\subsection{The Adoption Phase of Malay Culture}

Marhabanand plain flour is two things that cannot be separated. These two elements are traditions that usually appear in important ceremonies that accompany various important events in ethnic Malays, such as births, marriages, circumcisions, moving houses, clearing new lands, bringing enthusiasm for people who have just escaped distress. In Malay marriages, plain flour is a symbol of giving blessings for the welfare of the two brides and is used as a rejection of the reinforcements and disturbances of evil creatures. Fresh flour is a culture adopted from India which has been influenced by Islam. Every type of object in the plain flour ceremony is considered to have magical powers that function to save, cool, protect and so on.

This element is something new, appearing in the years according to the informants' recognition, namely the 1970s. The adoption of local cultural symbols is also seen in the hall which is also not commonly seen at wedding ceremonies held in Java. At the present time, marhaban is an element that is also considered important as something that must be carried out when they hold weddings and circumcisions. This element will always be present at every Javanese wedding ceremony in North Sumatra. This shows that the process of adopting symbols took place either from Java or from local culture.

Things that were not common in Javanese marriages on the island of Java, such as marhaban, plain flour, and balai appeared and were carried out by the Deli Javanese group. Even though in the adoption they do not understand for sure the meaning and meaning in these symbols, the values which represent a hope of blessings for the bride and groom and safety, and avoiding disturbance by supernatural beings become a picture of the beliefs of the Javanese Deli. All forms of objects that can be used as a repellent or avoiding a danger are very important to be implemented to make a celebration run successfully.

\section{Conclusion}

The culture of the Javanese Deli undergoes a process that is continuously being shaped and changed. From this paper shows that the identity of the Javanese Deli is very much influenced by situations and conditions that keep changing compared to when they were in Java. In line with Eriksen and Picard (Maunati, 2004: 25) who argue that ethnic identity is built according to the existing situation. Eriksen said that identity is situational and can change. In identity theory, the concepts of identity and even identity itself are seen as a result of the dynamic interaction between context (and history) and constructs. The identity of the Javanese Deli can be identified through the marriage ceremony that is carried out. But even though they adopted some elements of Javanese culture that are commonly used by Javanese people in Java and also elements of Malay culture, they still carry out their customs according to the results of the process of adjusting to their previous social situation. For example, in the nemokkan ceremony carried out by the Javanese Deli, there is a clear difference with the nemokkan ceremony carried out in Java. The equipment used shows a peculiarity that can only be found in the wedding ceremony of the Javanese Deli.

The adoption of Javanese identity markers was only carried out in the trend of clothing and aisle that was developing in Java. But other elements which are the result of a long historical process of social life and their interaction with priyai groups are retained. This can be seen from the makeshift equipment which is part of the equipment used in the nemokkan 
ceremony which are objects that are used by them everyday, and all of them symbolize the simplicity of life at that time. The equipment used in the nemokkan ceremony has its own meaning. The equipment used consists of: a mill which is usually used to smooth cooking spices, this thing is a symbol that the stone is not easy to pour water on and cause it to break, meaning that the millstone symbolizes slackness. Water in a place consisting of various kinds of flowers and called potpourri is used as a symbol of the two families that were previously unfamiliar and are currently one family. Chicken eggs in which there are white and yellow colors symbolize the heavens and the earth which are a complete and inseparable unity. The pestle symbolizes strength and the broomstick symbolizes one unified whole. The equipment used by the Javanese Deli shows a related relationship between the knowledge that is used as a guide for them in dealing with their environment. So the equipment is a form of behavior resulting from the existence of social life faced in plantations. The equipment is a representation of the simplicity of life,

These things are not commonly done in Java, as the cases described show that the culture of the Javanese Deli is a variant of Javanese culture. They continue to shape their identity which is expressed through traditions which are carried out by adopting several local cultural symbols such as marhaban, plain flour, and hall which are combined with Javanese culture which produces a distinctive cultural pattern that is only found in the Deli Javanese ethnic group.

\section{References}

Abdullah, Irwan. (2006). Konstruksi dan Reproduksi Kebudayaan. Yogyakarta: Pustaka Pelajar

Angkat, M., et al. (2019). Construction of Religious Identity in Pakpak Culture Community in Dairi District. Budapest International Research and Critics Institute-Journal (BIRCIJournal). P. 487-494.

Beatty, Andrew. (2001). Variasi Agama di Jawa. Jakarta: Raja Grafindo Persada

Breman, Jan. (1997). Menjinakkan Sang Kuli. Jakarta: Pustaka Utama Grafiti

Geertz, Clifford. (1976). Involusi Pertanian Proses Perubahan Ekologi di Indonesia. Jakarta: Bharata

Geertz, Clifford. (1981). Abangan, Santri, Priayi dalam Masyarakat Jawa. Jakarta: Pustaka Jaya

Khairani, et.al. (2015). "Cultural Identity Reproduction of Jawa Deli Through Marriage Ceremony".Research on Humanities and Social Sciences, vol. 12. https://core.ac.uk/download/pdf/234674605.pdf

Koentjaraningrat. (1978). Kebudayaan dan Mentalitas Pembangunan. Jakarta: Gramedia.

Lulofs, Szekely.(1985). Berpacu Nasib di Kebun Karet. Jakarta: Grafiti Pers

Lulofs, Szekely. (1985). Kuli. Jakarta: Grafiti Pers

Martozet and Nurwai. (2019). Sentimental Values in Tor-Tor Parsiarabu in Tomok Toba Samosir Village. Budapest International Research and Critics Institute-Journal (BIRCIJournal). P. 167-171.

Maunati, Yekti. (2004). Identitas Dayak Komodofikasi Politik dan Kebudayan. Yogyakarta: LKiS

Pelly, Usman. (1998). Urbanisasi dan Adaptasi. Jakarta: LP3ES

Pelzer, Karl J. (1985). Toean Keboen dan Petani. Jakarta: Sinar Harapan

Said, Mohammad. (1976). Sejarah Pers di Sumatera Utara dengan Masyarakat yang Dicerminkannya. Medan: Waspada 
Said, Mohammad. (1977). Koeli Kontrak Tempo Doeloe dengan Derita dan Kemarahannya. Medan: Waspada

Srinarwati, D. (2018). The Disclosure of Life Experience and Its Expression in Cultural Studies Perspective. Budapest International Research and Critics Institute-Journal (BIRCI-Journal). P. 125-141.

Stoler, Ann Laura. (2005). Kapitalisme dan Konfrontasi di Sabuk Perkebunan Sumatera, 1870-1979. Yogyakarta: Karsa

Suparlan, Parsudi. (1995). The Javanese in Suriname. Arizona: Program for Southeast Asian Studies

Thorir, Mudjahirin. (1999). Wacana Masyarakat dan Kebudayaan Pesisir. Semarang: Bendera Yudohusodo, Siswono. (1998). Transmigrasi, Kebutuhan Negara Kepulauan Berpenduduk Heterogen Dengan Persebaran Yang Timpang. Jakarta: PT Jurnalindo Aksara Grafika. 